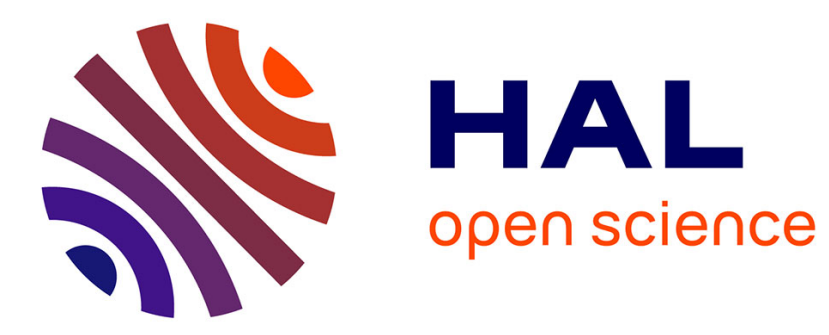

\title{
Structured hydrological analysis for targeting fallow evaporation to improve water productivity at the irrigation system level
}

\author{
S. Khan, M. M. Hafeez, T. Rana, S. Mushtaq
}

\section{- To cite this version:}

S. Khan, M. M. Hafeez, T. Rana, S. Mushtaq. Structured hydrological analysis for targeting fallow evaporation to improve water productivity at the irrigation system level. Hydrology and Earth System Sciences Discussions, 2007, 4 (1), pp.327-362. hal-00298816

HAL Id: hal-00298816 https://hal.science/hal-00298816

Submitted on 22 Feb 2007

HAL is a multi-disciplinary open access archive for the deposit and dissemination of scientific research documents, whether they are published or not. The documents may come from teaching and research institutions in France or abroad, or from public or private research centers.
L'archive ouverte pluridisciplinaire HAL, est destinée au dépôt et à la diffusion de documents scientifiques de niveau recherche, publiés ou non, émanant des établissements d'enseignement et de recherche français ou étrangers, des laboratoires publics ou privés. 
Hydrol. Earth Syst. Sci. Discuss., 4, 327-362, 2007 www.hydrol-earth-syst-sci-discuss.net/4/327/2007/ (C) Author(s) 2007. This work is licensed under a Creative Commons License.
Hydrology and Earth System Sciences Discussions

Papers published in Hydrology and Earth System Sciences Discussions are under open-access review for the journal Hydrology and Earth System Sciences

\section{Structured hydrological analysis for targeting fallow evaporation to improve water productivity at the irrigation system level}

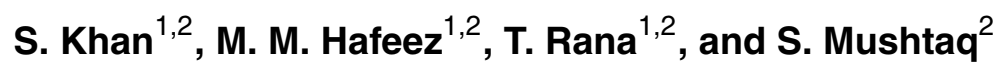

${ }^{1}$ CSIRO Land and Water Division, Locked Bag 588, Wagga Wagga, NSW 2678, Australia ${ }^{2}$ IC Water, Charles Sturt University, Locked Bag 588, Wagga Wagga, NSW 2678, Australia

Received: 14 February 2007 - Accepted: 18 February 2007 - Published: 22 February 2007 Correspondence to: S. Khan (shahbaz.khan@csiro.au)

HESSD

4, 327-362, 2007

Structured hydrological analysis for targeting fallow

evaporation

S. Khan et al.

\section{Title Page}

Abstract

Introduction

Conclusions

References

Tables

Figures

14

$>1$

4

Back

Close

Full Screen / Esc

Printer-friendly Version

Interactive Discussion 


\section{Abstract}

This paper provides results of an application of a holistic systematic approach of water accounting using remote sensing and GIS coupled with ground water modeling to evaluate water saving options by tracking non-beneficial evaporation in the Liuyuankou 5 Irrigation System (LIS) of China. Groundwater rise is a major issue in the LIS, where groundwater levels have risen alarmingly close to the ground surface (within $1 \mathrm{~m}$ ) near the Yellow River. The lumped water balance analysis showed high fallow evaporation losses and which need to be reduced for improving water productivity.

The seasonal actual evapotranspiration $\left(E T_{s}\right)$ was estimated by applying the SEBAL 10 algorithm for eighteen NOAA AVHRR-12 images over the year of 1990-1991. This analysis was aided by the unsupervised land use classification applied to two Landsat 5 TM images of the study area. SEBAL results confirmed that a significant amount (116.7 $\mathrm{MCM}$ ) of water can be saved by reducing $E T_{s}$ from fallow land which will result in improved water productivity at the irrigation system. The water accounting indicator

15 (for the analysis period) shows that the process fraction per unit of depleted water $\left(P F_{\text {depleted }}\right)$ is 0.52 for LIS, meaning that $52 \%$ of the depleted water is consumed by agricultural crops and $48 \%$ is lost through non-process depletion.

Finally, the groundwater modeling was applied to simulate three land use and water management interventions to assess their effectiveness for both water savings and impact on the groundwater in LIS. MODFLOW's Zone Budget code calculates the groundwater budget of user-specified subregions, the exchange of flows between subregions and also calculates a volumetric water budget for the entire model at the end of each time step. The simulation results showed that fallow evaporation could be reduced between $14.2 \%$ (25.51 MCM) and 45.3\% (81.36 MCM) by interventions such as canal 25 lining and ground water pumping. The reduction in non-beneficial $E T_{s}$ volumes would mean that more water would be available for other uses and it would allow the introduction of more surface water supplies in the area through improved water management strategies. This will ultimately lead to improved water productivity of the LIS system.
HESSD

4, 327-362, 2007

Structured

hydrological analysis

for targeting fallow

evaporation

S. Khan et al.

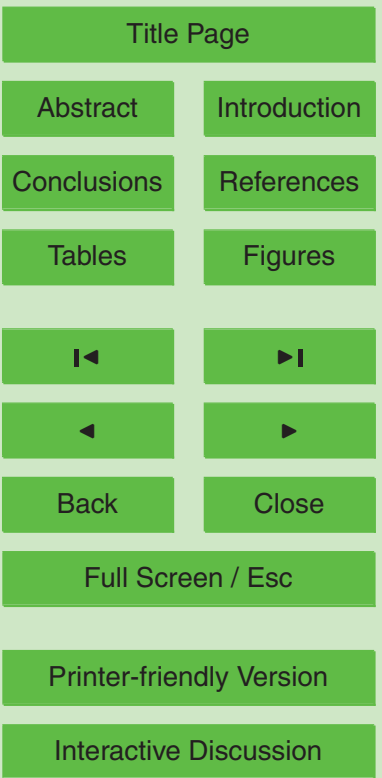




\section{Introduction}

Water scarcity is becoming a critical issue in the lower Yellow River Basin, which is an important food production area of China. Farmers in the basin are under pressure to grow more "crop per drop" (Khan et al., 2007). To address the water scarcity, scien5 tists often recommend a "soft path" to increase overall water productivity (Rijsberman, 2006). Several field level water saving technologies have been developed under the water scarcity scenarios and delivered to farmers to reduce water inputs at the farm level (Khan et al., 2006). However, few studies have evaluated the impact of water saving technologies in the broader spectrum of the irrigated agricultural system and river 10 basins, where the water balance components and associated benefits are intricately interlinked for various spatial and temporal domains.

One possible way is to measure irrigation efficiency, which is the most commonly used term to describe how well water is being used at any spatial scale (Molden and Sakthivadivel, 1999). However, the quantification of irrigation efficiency requires the complete understanding of the spatial water balance components and its link at various scales such as field, farm, irrigation system and basin level. Molden (1997) pointed out several weaknesses in using efficiency terms and scale effects when shifting analysis from field level to irrigation systems and river basins, and presented a common framework to describe water use within a basin, i.e., water accounting.

20 This study focused on the Liuyuankou Irrigation System (LIS) (Fig. 1) in the lower Yellow River Basin, where irrigation has been operational from 1958, stopped in 1961, then restarted in 1967 after the construction of new headwork at the Yellow River (Loeve et al., 2003). Irrigation for crop production is met by surface water drawn from the channels diverted from the Yellow River (YR), mainly in the northern part of LIS 25 (situated above the railway line and hereafter known as "ARL"). However, due to higher seepage loss from the sandy canals to the underlying permeable aquifers, surface water is not enough to supply the whole system. In the southern part of LIS (situated below the railway line and hereafter known as "BRL") crops are generally grown with
HESSD

4, 327-362, 2007

Structured

hydrological analysis

for targeting fallow

evaporation

S. Khan et al.

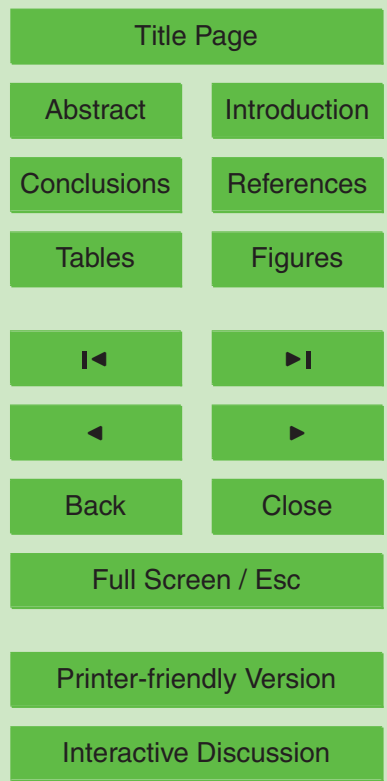


water sourced by groundwater pumping. Despite the improved efficiency and the presence of a drainage system, the groundwater table has risen alarmingly in the upstream areas (within $1 \mathrm{~m}$ of land surface), in the ARL part of LIS (Zhu et al., 2003). As a result, Khan et al. (2006) reported that a significant amount of the irrigation water leaves

5 LIS through fallow evaporation and its reduction is therefore critical to increase water productivity. However, the reduction of fallow evaporation is only possible if we have a reliable spatio-temporal quantification of actual water consumption which will help us to identify areas having high non-beneficial evaporation in LIS.

Seepage from irrigated fields in the ARL part is an important source of recharge to 10 the BRL part of LIS. The lateral outflow through the aquifer is very small compared to the total seepage from the Yellow River. On the other hand, too much seepage and lateral recharge from the river decreases irrigation water use efficiency and results in shallow ground water levels that cause secondary soil salinization. Kahlown et al. (2002) reported that water-table depths less than $1 \mathrm{~m}$ significantly decrease yields of crops with the exception of rice. In addition to this, without enough lateral recharge to lowland ground water, ground water depths have increased in groundwater-dependent areas and the cost of groundwater abstraction has increased; in some cases resulting in overdraft conditions. This feature of the system could cause substantial yield decline in the future, and may cause severe constraints to both agricultural and economic development. There is an urgent need to save a substantial amount of water lost from fallow evaporation and crop transpiration in the ARL side of LIS, and introduce more surface water supplies in the ground water-dependent areas through improved water management strategies. Khan et al. (2006) reported that there are high evaporation losses from fallow land and high seepage losses from the Yellow River using lumped water balance analysis over 10 years.

To save a substantial amount of water lost, maintain groundwater levels to prevent evaporation and salinisation in the ARL (areas adjacent to Yellow River), and to reduce the cost of abstraction in the BRL (areas far away from Yellow River) various water management options were investigated. To evaluate these water management
HESSD

4, 327-362, 2007

Structured

hydrological analysis

for targeting fallow

evaporation

S. Khan et al.

Title Page

Abstract

Introduction

Conclusions

Tables

References

Figures

14

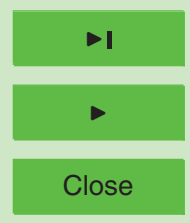

Back

Full Screen / Esc

Printer-friendly Version

Interactive Discussion 
options, a systematic approach was applied with a combination of water accounting using remote sensing and Geographic Information System (GIS) coupled with ground water modeling for measuring irrigation water productivity.

The particular objectives of this study were; a) to compute spatial distribution of 5 seasonal actual evapotranspiration $\left(E T_{s}\right)$ of different land uses using remote sensing techniques over LIS; b) to estimate water accounting and productivity of LIS; and c) groundwater modeling to develop and test different scenarios for future water savings and quantify associated gains in water productivity.

\section{Key features of the study area}

10 The LIS is located on the right bank of Yellow River in North West China, more precisely in Kaifeng County (Fig. 1) and is part of the Hui Ji River system (Huai He River basin). The geographic boundary of the LIS rang from $114.35 \mathrm{E}$ to $114.78 \mathrm{E}$ and from $34.58 \mathrm{~N}$ to $34.89 \mathrm{~N}$. The LIS has a temperate continental monsoonal climate with cool, dry winters and warm, wet summers. Mean annual temperature is $14.1^{\circ} \mathrm{C}$ and the frost15 free days are 210 240 days. Mean annual evaporation is $1316 \mathrm{~mm}$ and the maximum evaporation occurs from March to August. The total area of LIS is 55512 ha with the net irrigated command area of 40724 ha and cropping intensity is about 1.43.

During recent years, irrigation conditions have become more efficient due to the improvement and maintenance of the hydraulic structures on the main channels. In spite of this improved efficiency and the presence of a drainage system, the ground water table has risen alarmingly in $A R L$ and $B R L$. Due to intensive local groundwater pumping within the $B R L$ area, the lateral outflow of the aquifer is very small compared to lateral seepage into the area. Conversely, in the ARL the ground water aquifer is already full and there is risk of soil salinisation if hydraulic loading due to rice is reduced, the overall ground water outflow from the LIS is very small, this area is a net salt sink and is recycling these salts through the system by ground water pumping in the BRL

HESSD

4, 327-362, 2007

Structured hydrological analysis for targeting fallow evaporation

S. Khan et al.

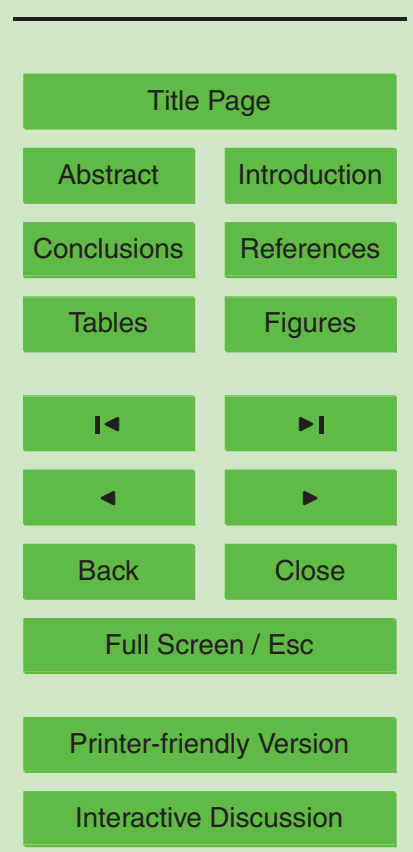

EGU 


\section{Materials and methods}

Figure 2 describes the conceptual diagram for structured hydrological analysis at the system level. First, the water balance analysis was completed and water balance was 5 closed by lumping runoff and fallow evaporation since no data on runoff was available. SEBAL algorithm based on remote sensing technique was used to estimate $E T_{s}$ in a spatio-temporal distributed format. The output of SEBAL was used in water accounting framework to know whether how much water was used beneficially and non-beneficially in an irrigation system. Finally, groundwater modeling of the system was carried out to develop different land and water management scenarios in LIS which provided a path way to improve water productivity of irrigation system.

\subsection{Hydrological data collection for water balance}

In LIS, precipitation varies both temporally and spatially. There is a great difference in average monthly precipitation at Hubei station for the period 1988 to 2000 . Mean 15 annual precipitation is $627 \mathrm{~mm}$, of which $70-80 \%$ falls in the June to September period due to monsoon activity. The rainfall data was manually observed and recorded twice a day. The volume of rainfall was calculated by multiplying the area with quantity of rainfall. The reference evapotranspiration $\left(E T_{o}\right)$ was calculated using modified Penman-Montieth method from the meteorological data of Hubei meteorological station (Allen et al., 1998). The crop coefficients of the major crops in the LIS were obtained by knowing the crop development stages for each month. Crop water consumption was obtained by multiplying the respective crop coefficient by $E T_{o}$ value for each corresponding month.

The major canal in LIS is located in the upper part of the irrigation district, and feeds three main canals and fourteen branch canals. The discharge of the main canal was

Structured

hydrological analysis

for targeting fallow

evaporation

S. Khan et al.

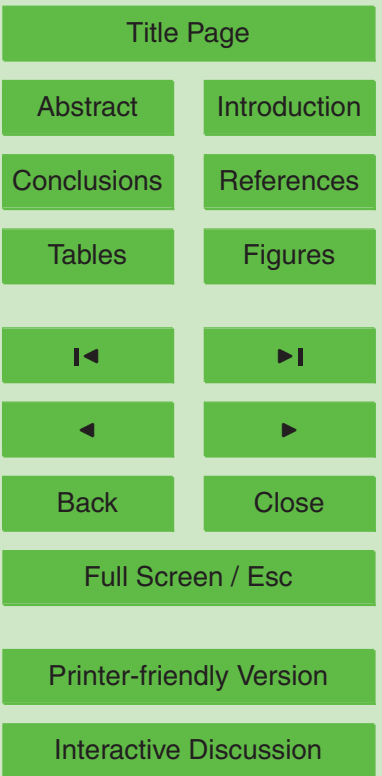

EGU 
converted to determine the equivalent volume of water by multiplying the discharge with time. The total volume of water was estimated by summing up the discharge of the inflow point for each year.

The major crops cultivated in the LIS include winter wheat, summer maize, cotton, 5 rice and soybean. The yield data were obtained from weekly monitoring activity of the irrigation department at LIS. Wheat is the major crop grown over almost all of the area during the winter season, whereas the other major crops are rice, cotton, maize, and soybean during the summer season.

The lumped water balance (INFLOW - OUTFLOW = Change in groundwater stor10 age) was carried out for the period of 1988 to 2000 for LIS. Change of groundwater volumes between successive years was estimated, and multiplied by the specific yield of the aquifer, assumed as 0.15 . These volumes represent the change in water storage. If change in groundwater storage is negative then inflows are greater than outflows; if change in groundwater storage is positive then inflows are smaller than outflows. The 15 lateral inflow (seepage) was estimated using the MODFLOW model by knowing the hydraulic conductivity of the area. This water balance was closed by lumping runoff and fallow evaporation since no data on runoff was available.

\subsection{System level approach using remote sensing}

Remote sensing techniques were used to estimate fallow evaporation in the absence

of surface runoff. A major proportion of these losses are likely to be due to fallow evaporation because runoff is small due to agricultural development. However, it is only possible after the identification of fallow land through land use classification and then verification of fallow evaporation figures through advanced tools like remote sensing which provides a more realistic estimation of actual evapotranspiration $\left(E T_{a}\right)$ in a 25
HESSD

4, 327-362, 2007

Structured

hydrological analysis

for targeting fallow

evaporation

S. Khan et al.

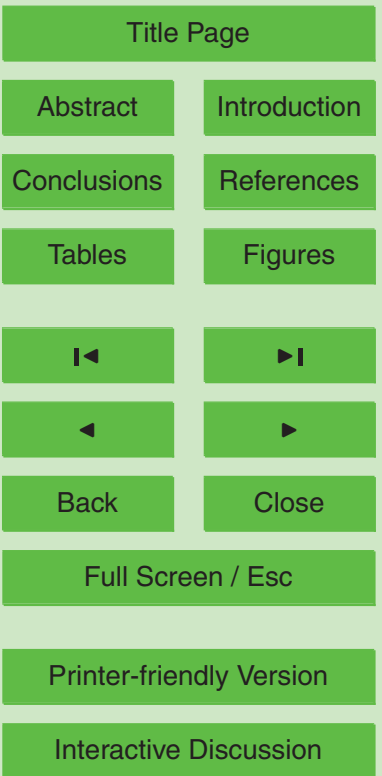




\subsubsection{Land use classification}

Two Landsat 5 TM images covering the LIS were used to assess land use at different stages of the growing season i.e. 2 September 1990 for the summer season and 20 January 1991 for the winter season. A subset of LIS using false color composite (FCC) 5 of satellite images (Landsat 5 TM) was created after geo-referencing the image in the UTM Zone 51, WGS84 using 40 well distributed ground control points (GCP) with root mean square error (RMSE) of less than 1 pixel size.

The land use classification of summer season 1990 was performed using a series of consecutive unsupervised classification steps. The unsupervised classification has been carried out on the basis of the ISODATA clustering algorithm. Three ISODATA clustering attempts have been performed, using respectively 5,10 and 20 clusters. The ISODATA clustering with 6 classes has been used to separate bare soil, settlement, fallow land, water, agriculture crops, and unclassified (mainly clouds). A limited ground truth data with 87 records of the major land use classes for the summer season was available through land cover database of the local irrigation department. This database has been used to assign the ISODATA clustering results to land cover classes.

The same ISODATA clustering methodology as applied for the summer season has been applied for the winter season of 1990-1991. Similarly, ground truth data with 57 records of the major land use classes for the winter season was available through land cover database of the local irrigation department. Despite that such land cover dataset is not sufficient to cover variability in farmer's field conditions; the database has been used for the interpretation of the ISODATA results. The six major land use classes for winter season are bare soil, settlement, fallow land, water, agriculture crops and unclassified.

\subsubsection{Seasonal actual evapotranspiration}

Satellite remote sensing is a powerful means to provide $E T_{a}$ measurement at a wide range of spatial scales ranging from individual pixels to an entire raster image, and

HESSD

4, 327-362, 2007

Structured

hydrological analysis

for targeting fallow

evaporation

S. Khan et al.

\section{Title Page}

Abstract

Introduction

Conclusions

Tables

References

Figures

14

4

Back

Full Screen / Esc

Printer-friendly Version

Interactive Discussion 
has attracted many scientists for the last 20 years (Hafeez, 2003). The use of these remote sensing techniques have become increasing popular due to the relatively low cost of data collection, just $\$ 0.03 /$ ha for irrigated lands (Sakthivadivel et al., 1999). This study focused on Surface Energy Balance Algorithm for Land (SEBAL), developed by

5 Bastiaanssen (1995) to estimate $E T_{a}$ from agricultural areas using optical and thermal satellite imagery. SEBAL is a thermodynamically based model, which partitions between sensible heat flux and latent heat of vaporization flux.

NOAA AVHRR imagery is one of the most stable sources of information available publicly from Internet. It covers consequent areas $(1000 \times 3000 \mathrm{~km})$ while having a spa10 tial resolution $(1 \times 1 \mathrm{~km})$ at the merging of climatic and agricultural applications. A set of 18 NOAA AVHRR-12 images were downloaded from Internet through the Satellite Active Archive website, which has publicly available satellite imagery archives which were covering different time periods of the year (April 1990 to March 1991) over the study area (see Table 1).

15 3.2.3 Specificity of porting SEBAL to NOAA-AVHRR

A subset image for the study area was created for better visualization, and georeferencing was done using 40 well distributed ground control points in the UTM Zone 51 , WGS84, with a RMSE of less than half pixel size. The pre-processing parameters required for SEBAL include the Normalized Difference Vegetation Index (NDVI), broad20 band surface albedo, emissivity, and surface temperature. The NDVI was calculated from bands 1 and 2 of NOAA-AVHRR, and the broadband albedo was calculated using weighing factors of visible bands of NOAA-AVHRR. Surface emissivity $(\Delta \varepsilon)$ of the sensor was calculated from the NDVI using an algorithm developed by Bandara (1998). The brightness temperature is the temperature detected by a thermal sensor. First, 25 radiance data from thermal bands (4 and 5) are converted to brightness temperatures using an inversion of Planck's equation. A split window algorithm was used to calculate surface temperature from thermal bands 4 and 5 . The authors applied the algorithm developed by Price (1984) for this study because Vazquez et al. (1997) claimed that it
HESSD

4, 327-362, 2007

Structured

hydrological analysis

for targeting fallow

evaporation

S. Khan et al.

Title Page

Abstract

Conclusions

Tables

Figures

14

4

Back

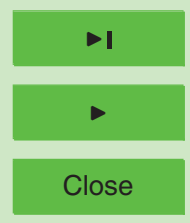

Full Screen / Esc

Printer-friendly Version

Interactive Discussion

EGU 
performed better than other algorithms. More detailed information about the porting of SEBAL for NOAA-AVHRR can be found in Hafeez and Khan (2006).

The $\Lambda$, evaporative fraction, is the output of SEBAL and is defined as the ratio of latent heat to maximum net available energy as in Eq. (1);

${ }_{5} \wedge=\frac{\lambda E}{R_{n}-G_{0}}=\frac{\lambda E}{\lambda E+H_{0}} \quad(-)$

where $\lambda E=$ latent heat flux (the energy allocated for water evaporation). $\lambda$ can be interpreted in irrigated areas as the ratio of actual evaporation to crop potential evaporation. It is dependent on the atmospheric and soil moisture conditions equilibrium; $R_{n}=$ net radiation absorbed or emitted from the earth's surface (radiative heat) $\left(\mathrm{W} / \mathrm{m}^{2}\right) ; G_{0}=$ soil 10 heat flux (conduction) $\left(\mathrm{W} / \mathrm{m}^{2}\right)$ and $H_{0}=$ sensible heat flux (convection) $\left(\mathrm{W} / \mathrm{m}^{2}\right)$

The daily actual $E T$ is calculated in SEBAL (more details can be found in Hafeez and Khan, 2006) from the instantaneous evaporative fraction, $\Lambda$, and the daily averaged net radiation, $R_{n 24}$. The latter has to be transformed from $\mathrm{W} / \mathrm{m}^{2}$ to $\mathrm{mm} /$ day by the $T_{0}$-dependent latent heat of the vaporization equation inserted in the main equation 15 (Eq. 2).

$E T_{24}=\Lambda \times\left[R_{n 24} \times\left(\left(2.501-0.002361 \times T_{0}\right) \times 10^{6}\right)\right] \quad(\mathrm{mm} /$ day $)$

where $E T_{24}=$ Daily $E T$ actual $(\mathrm{mm} /$ day $) ; R_{n 24}=$ average daily net radiation $\left(\mathrm{W} / \mathrm{m}^{2}\right)$; and $T_{0}=$ surface temperature $\left({ }^{\circ} \mathrm{C}\right)$

The $E T_{a}$ calculation through remote sensing on specific dates provided a good in20 dication of its spatial distribution in the irrigation system. However, this information could not be used directly, as $E T_{a}$ directly depends upon weather conditions and water availability in the field, which varies from day to day. It was therefore necessary to simulate daily values to get an accurate estimation of $E T_{s}$. A larger sample of timely $E T_{a}$ observations is necessary to obtain an accurate result and to adjust the daily fluctuation of $E T_{a}$ for integration of $E T_{s}$. $E T_{s}$ was estimated spatially by adding the satellite images together following a daily weight ratio corresponding to the number of days
HESSD

4, 327-362, 2007

Structured

hydrological analysis

for targeting fallow

evaporation

S. Khan et al.

\section{Title Page}

Abstract

Introduction

Conclusions

Tables

References

Figures

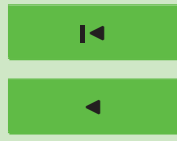

$\rightarrow I$

Back

Close

Full Screen / Esc

Printer-friendly Version

Interactive Discussion

EGU 
representing each image time period (April 1990 to March 1991) cover over the study area. This method is found in Tasumi et al. (2001), and is a "classical" step approach in the integration of individual values over a certain dimension. Hafeez and Khan (2006) described in detail the procedure of obtaining $E T_{s}$.

\section{$5 \quad 3.2 .4$ Confirmation of $E T$ from fallow land}

The next step was to determine the amount of water consumed by $E T_{s}$ from the different land use classes for satellite overpass dates in 1990-1991. First, a land use classified image for each satellite overpass was transformed into land use polygons for the said period, and similarly a SEBAL derived $E T_{s}$ map was also transformed into 10 polygons. Finally, the land use polygons map was overlaid on the $E T_{s}$ map and an $E T_{S}$ map from all polygons of each class was computed for each satellite overpass.

\subsection{Water accounting and productivity}

The water accounting procedure, based on a water balance approach, was applied to measure water use and water productivity in the LIS system. Water accounting defines the amount of water within the system by classifying inflow, outflow, water depletion through evapotranspiration (process and non-process), and available water among different users with in an irrigation system. The clear understanding of all the components of water accounting will lead to a measure of true water saving. The water accounting and its indicators are presented in the form of fractions and in terms of productivity of water, and are explained in Molden, 1997. All water accounting components, i.e., surface inflow and outflow, rainfall, water pumped from ground water, storage change, $E T_{a}$ (agricultural crops and non-agricultural crop), and rice yields were measured for 1990-1991 at LIS. Three types of water accounting indicators, which are alternative to the classical irrigation efficiencies, are used in this study: physically based indicators (depleted fractions), beneficial utilization indicators (process fraction) and water productivity indicators (Molden and Sakthivadivel, 1999). More details on water ac-

HESSD

4, 327-362, 2007

Structured

hydrological analysis

for targeting fallow

evaporation

S. Khan et al.

Title Page

Abstract

Introduction

Conclusions

Tables

References

Figures

14

4

Back

Close

Full Screen / Esc

Printer-friendly Version

Interactive Discussion 


\subsection{Groundwater modeling}

The main purpose of the ground water modeling was to simulate alternative land use and water management options to assess their effectiveness for water saving and im5 pact on the groundwater in LIS. The ground water system for the LIS consists of three distinct aquifer systems separated by clay layers. The connection between the shallow (30 to $40 \mathrm{~m}$ deep) and moderately deep (40 to $100 \mathrm{~m}$ depth) aquifers is better than that between the moderately deep and deeper aquifers (>100 $\mathrm{m}$ depth). These aquifers are separated by aquitards with 1 to $2 \mathrm{~mm}$ /day vertical leakage. The general direction of 10 regional groundwater flow is from north $(A R L)$ to south $(B R L)$ due to lateral flow from the Yellow River.

A surface-groundwater interaction model for the LIS was developed to understand the groundwater dynamics. The US Geological Survey model MODFLOW coupled with the MT3D solute transport simulator under a PMWIN environment were used as the modelling framework. The spatial domain represented in the model consists of four layers each of 77 rows and 84 columns $(500 \mathrm{~m} \times 500 \mathrm{~m}$ cell size $)$. A stress period length of 6 months was used to enable simulation of irrigation and non-irrigation seasons with a computational time step of one day. Initially the model parameters were specified for the 1990 to 2002 period for calibration purposes. Extensive datasets on the aquifer lithology, piezometric levels, aquifer abstractions, channel network, Yellow River and rice area locations were collected and collated in ArcView GIS format. Figure 3 shows the MODFLOW model domain of the LIS area.

After the development of the working surface-groundwater interaction model, calibration of the model was carried out. The first step in model calibration is the identification of the calibration targets. Observed water levels in the LIS area were used for calibration purpose. The second step consists of determining the acceptable range of errors between simulated and measured calibration targets. These errors, or differences in heads, are referred to as residuals. Residual heads are defined as the observed water

Structured hydrological analysis for targeting fallow evaporation

S. Khan et al.

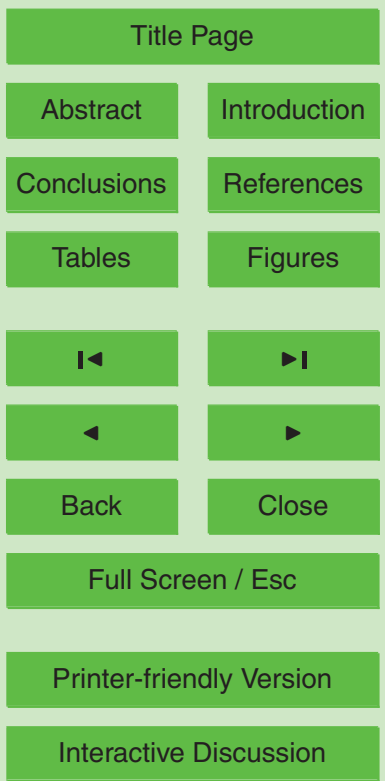


levels minus the simulated water levels. As the third step, trial-and-error and inverse simulations are performed until simulated parameters are within the acceptable range of errors. For this study a combination of PEST and UCODE methods (inverse modelling techniques) were used to calibrate the model. Both codes perform the calibration 5 process by taking control of the model (MODFLOW) and running it as many times as is necessary in order to determine the optimal set of parameters.

\section{Results and discussion}

\subsection{Water balance}

Loeve et al. (2003) reported that the total cultivated area has been fairly constant during 10

rized in Table 2. The water balance was closed by lumping runoff and fallow evaporation since no data on runoff was available. Table 3 summarizes the yearly average results of all the components of the water budget for LIS. The lateral seepage from the Yellow River ranges from 85 to $95 \mathrm{MCM}$ /year. The yearly surface water diversions 15 from the Yellow River range from 7 to 162 MCM. . The computation of the water balance components for the period 1988-2000 as summarized in Table 3, showed that the greatest unaccounted flows from the LIS are through fallow evaporation and runoff out of the area and can be in the range of $50 \%$ of the total inflow. Khan et al. (2006) reported that high evaporation occurs in the upland area (ARL) which is due to shallow water tables in that part of the LIS, while the beneficial ET (crop ET) accounts for about $20 \%$. Lateral outflow of groundwater is minimal and is in the vicinity of $1 \%$ of the total outflows from the system. Inflows to the LIS are dominated by rainfall, which also makes up about $56 \%$ of the recharge to the groundwater. The average Yellow River lateral seepage is in the same range as the water diversion from the Yellow River and
HESSD

4, 327-362, 2007

Structured

hydrological analysis

for targeting fallow

evaporation

S. Khan et al.

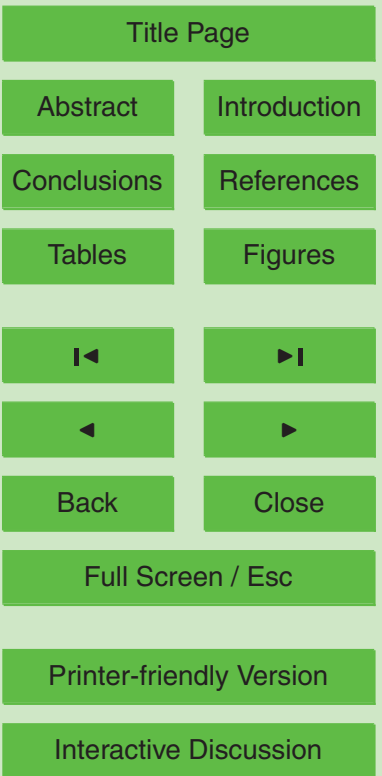


Unsupervised classification scheme (ISODATA clustering algorithm) was employed for each satellite image to get information about various land use/land cover classes in LIS. Overall, the land use/land covers identified for 1990-1991 were: agricultural crops, 5 fallow land, bare soil, settlements, water bodies, and unclassified (Fig. 4).

The accuracy of the classification depends on several factors, such as the spectral separability of the land cover classes, heterogeneity of the land surface, and the number of ground truth samples. The accuracy of the current classification is aggravated by the fact that the agricultural plots have a small size and that most ground truth samples originate from a limited area. More ground points will improve the accuracy of the classification. The results of land use classification were validated by limited ground truth data available from local irrigation department of LIS. A percentage of $5 \%$ for field canals, $5 \%$ for field bunds and $4 \%$ for field roads are subtracted from the total area classified as agriculture crops.

Agriculture crops were classified with accuracy greater than $84 \%$ and the overall accuracy and kappa coefficient associated with classification are $80 \%$ and 0.78 , respectively. The results of land use classification were also compared with the public data available from irrigation department about the major crops grown in LIS during the summer and winter season of 1990-1991.

\subsection{Seasonal actual evapotranspiration}

The $E T_{s}$ map on a pixel-by-pixel basis was produced through integration of all daily $E T_{a}$ images for the 1990-1991 period (see Fig. 5). Figure 5 depicts a range from $259 \mathrm{~mm}$ to $800 \mathrm{~mm}$ of $E T_{s}$ in the LIS region for the season of 1990-1991. Low $E T_{s}$ is modelled for the bare fields and fallow lands, while the irrigated areas range from medium to high $E T_{s}$. The agricultural fields in ARL area have higher $E T_{s}$ values due to shallow water table, lateral seepage from the yellow river and a leaky network of irrigation canals. Higher $E T_{s}$ values are indicated by darker black color in Fig. 5. The BRL
HESSD

4, 327-362, 2007

Structured

hydrological analysis

for targeting fallow

evaporation

S. Khan et al.

\section{Title Page}

Abstract

Introduction

Conclusions

Tables

References

Figures

14

4

Back

Close

Full Screen / Esc

Printer-friendly Version

Interactive Discussion 
areas have lower $E T_{s}$ values because the water table is relatively deep and there is no surface water irrigation network. Lower $E T_{s}$ values are indicated by light grey color. The $E T_{s}$ map further shows a spatial gradient of decreasing evapotranspiration from the Northern (ARL) parts towards the Southern parts (BRL) of the irrigation system. 5 The irrigated fields (dark black color) can be differentiated from the non- irrigated fields (light grey color) at a spatial resolution of NOAA-AVHRR $(1000 \mathrm{~m})$ for LIS.

The pixel values of $E T_{a}$ calculated through SEBAL, in the area surrounding Hubei meteorological station, were compared with the measured evaporation through Class A Pan $\left(E_{\text {pan }}\right)$, and $E T_{C}$ from Hubei meteorological station for 1990-1991 as shown in 10 Fig. 6. There is a significant difference in $E T$ values obtained from remote sensing and classical techniques which utilize weather station data. The former provides spatial distribution results, whereas the latter provides only point values.

As shown in Fig. 6, $E_{\text {pan }}$ values from Hubei meteorological stations were always higher (on average $21 \%$ ) than $E T_{a}$ values for all image acquisition dates. For pixels 15 assumed to be under crop, the estimated $E T_{a}$ was on average $6 \%$ lower than the average $E T_{c}$ calculated from the weather station. The comparison provides an indication of the amount of confidence that can be given to the values of $E T_{a}$ derived from the remote sensing images. The $E T_{a}$ is estimated from all the physical mediums within one pixel, which might have mixed spectral signatures of road, settlement, and rice fields.

Due to the large pixel size of NOAA-AVHRR, it was difficult to absolutely compare such information with the classical point data from meteorological data, even though Fig. 6 shows a good trend regarding the accuracy of $E T_{a}$ derived from the SEBAL.

However, the accuracy of this comparison of modeled against measured data needs to be considered with respect to scale. Modeled area data was derived from discrete 25 areas of one square kilometer (spatial resolution of a NOAA-AVHRR sensor) and would therefore contain reflectance attributes from many different physical mediums (mixed spectral signatures from rice fields, bare fields, and roads) and a resulting combined evapotranspiration rate. Comparison between the modeled data and the point-based measured data from class A Pan or meteorological stations introduces the possibility
HESSD

4, 327-362, 2007

Structured

hydrological analysis

for targeting fallow

evaporation

S. Khan et al.

\section{Title Page}

Abstract

Conclusions

Tables

Figures

14

4

Back

Full Screen / Esc

Printer-friendly Version

Interactive Discussion 
of scale related errors. Even though a comparison of $E T_{a}$ with $E_{\text {pan }}$, and $E T_{c}$ does not bring sufficient absolute elements for validation, it does contribute to a consistency cross-check for the $E T_{a}$ calculation from SEBAL. The comparison shows similar trends in $E T$ in the time domain of 1990-1991.

\section{4.3.1 Confirmation of $E T$ from fallow land}

The land use polygons map was overlaid on the $E T_{s}$ map and $E T_{s}$ map from all polygons of each class was computed for each satellite overpass. Results showed that a high amount of water (179.62 $\mathrm{MCM}$ ) is lost through non-beneficial $E T_{s}$ including fallow land, bare soil, water bodies and others during 1990-1991 (Fig. 7). Similarly, a high 10 amount of water (116.7 MCM) is lost through $E T_{s}$ from fallow land during 1990-1991 (Fig. 7).

Lumped water balance analysis showed that fallow $E T$ including runoff is equivalent to $166 \mathrm{MCM}$. The remote sensing derived $E T_{s}$ also confirm that a huge amount of water can be saved by reducing evaporation from the fallow land. The $E T_{s}$ of agricultural crops (wheat, rice, cotton, maize, and soybean) are treated as process depletion for different sub-areas of LIS.

\subsection{Water accounting and productivity}

Results of process fraction and depleted fraction indicators are summarized in Table 4. The process fraction per unit of gross inflow $\left(P F_{\text {gross }}\right)$ at LIS is 0.32 which means that depleted water (PF $)$ is 0.52 for LIS, meaning that $52 \%$ of the depleted water is consumed by the agriculture crop and $48 \%$ is lost through non-process depletion. The results also prove earlier findings of Khan et al. (2006) that a high amount of water is depleted through non-process depletion for LIS. The depleted fraction per unit of gross inflow $\left(D F_{\text {gross }}\right)$ is 0.61 at LIS, means that $39 \%$ of the gross inflow (rainfall, irrigation, and groundwater) is flowing out of LIS. Meanwhile, the second indicator, $D F_{\text {available, }}$,
HESSD

4, 327-362, 2007

Structured

hydrological analysis

for targeting fallow

evaporation

S. Khan et al.

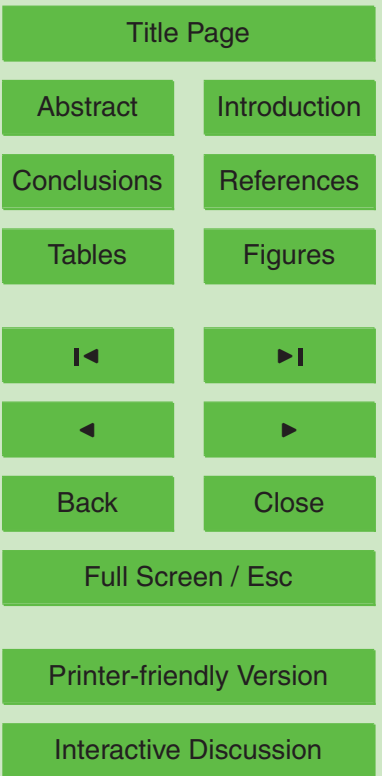

EGU 
can be interpreted as irrigation system efficiency. The value of $D F_{\text {available }}$ is 0.70 which shows that $70 \%$ of the available water is depleted. The water productivity per unit of gross inflow and water productivity per unit of net inflow is $0.39 \mathrm{~kg} / \mathrm{m}^{3}$ and $0.42 \mathrm{~kg} / \mathrm{m}^{3}$. The water productivity per unit of irrigation water $\left(W P_{\text {irrigation }}\right)$ is $1.52 \mathrm{~kg} / \mathrm{m}^{3}$. Similarly,

5 the water productivity per unit of crop evapotranspiration is $1.23 \mathrm{~kg} / \mathrm{m}^{3}$ for the cropping season of 1990-1991. Loeve et al. (2003) reported that the $W P_{\text {irrigation }}$ ranges from $1.75 \mathrm{~kg} / \mathrm{m}^{3}$ at the first main canal command (28519 ha) to $2.98 \mathrm{~kg} / \mathrm{m}^{3}$ at the second main canal command (160206 ha) in Zhanghe Irrigation System (ZIS) in China. The major reason of low water productivity in LIS is high non-beneficial evaporation from 10 the fallow land and there is huge potential of improving water productivity by reducing non-beneficial evaporation.

\subsection{Groundwater modelling}

The main purpose of the ground water modeling was to simulate different land use and water management options to assess their effectiveness for reducing fallow evaporation 15 and impact on the groundwater in LIS. In the LIS model, there are 6468 active cells per model layer. There are 3 layers and the model inputs that could be altered include leakage between layers, storage, hydraulic conductivity and conductance of channels. This equates to a possible 118860 input variables that can be altered to achieve the calibration target. During model calibration it is desirable to compare the calculated and 20 observed head on original piezometer data rather than interpolated piezometer data because of the uncertainty involved in the interpolation process. However, interpolated piezometer data has the advantage of being available in every model cell, making it easier to judge the success or failure of every model cell to replicate observation. A set of 60 piezometer's hydrographs was used for dynamic history matching.

Information about the average annual groundwater recharge (computed using a detailed water balance) in the LIS is summarized in Table 5. The calculated average yearly lateral recharge from Yellow River into the LIS area is 89 MCM which represents
HESSD

4, 327-362, 2007

Structured

hydrological analysis

for targeting fallow

evaporation

S. Khan et al.

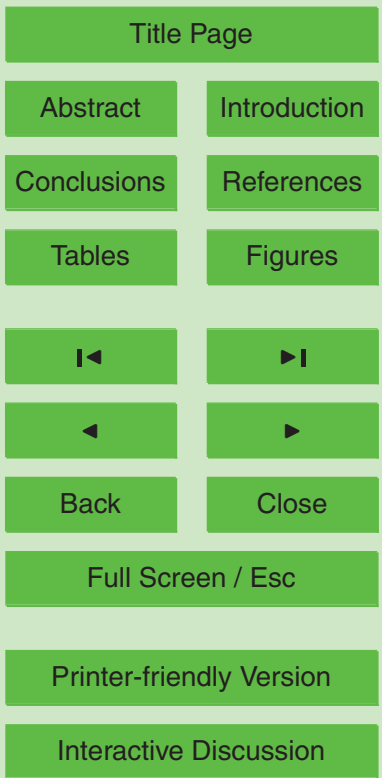


$33 \%$ of the total groundwater recharge. Lateral recharge from the Yellow River was calculated using the hydraulic gradient between the Yellow River water levels and the ground water levels in the recharge area, the flow area, and aquifer properties. Rainfall contributes $55 \%$ of recharge over the LIS.

5 The major factors affecting recharge in the area include rice fields, irrigation channels, ditches upstream of the railway line and distributed rainfall over the LIS area. Salinity in the crop areas of ARL is dominated by local recharge due to rice irrigation and lateral groundwater flow from the Yellow River. Urban pumping in the adjacent Kaifeng city has induced a major groundwater depression, with water tables levels 10 falling more than $20 \mathrm{~m}$ by 1983 . This situation was rectified by reducing groundwater pumping since 1983, and the present maximum depth to water tables in the center of the groundwater depression is around $17 \mathrm{~m}$. The area of the groundwater depression under Kaifeng city is greater than $150 \mathrm{~km}^{2}$.

\subsubsection{Possible future development options}

15 In recent years, due to a decrease in surface water from the Yellow River, some water saving irrigation techniques have been introduced in the upland rice fields. Canal lining is also believed to be an effective way to reduce losses and save water. These changes result in a reduction in the recharge to groundwater. The calibrated surfacegroundwater interaction model was used to simulate possible future management sce20 narios to overcome the decrease in surface water supply from the Yellow River. Considering the existing groundwater conditions (December 2002) as "initial conditions", a number of future scenarios are evaluated by simulating the response of groundwater levels under the changed water management conditions over the next 20 years. All the parameters/assumptions used on hydro-geological characteristics of the sys25 tem remain the same. Recharge rates from rainfall, heads in the Yellow River and $E T_{0}$ for 1990-2002 are used for the 2003-2023 period, assuming no significant increase/decrease in the hydro-climatic conditions or flows of the Yellow River is envisaged in the near future.

\section{HESSD}

4, 327-362, 2007

Structured

hydrological analysis

for targeting fallow

evaporation

S. Khan et al.

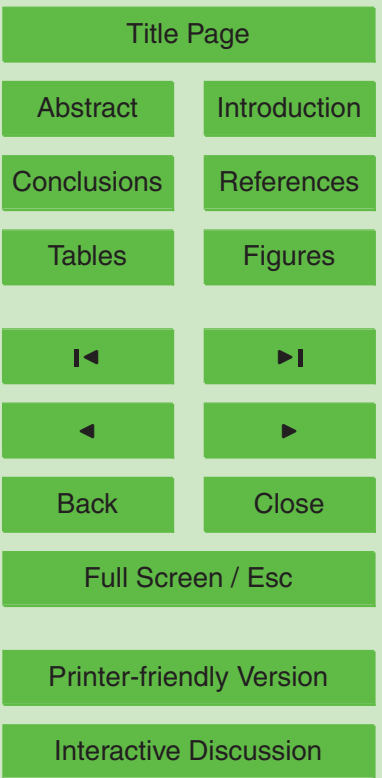


The following future scenarios are studied:

- Scenario 1: Baseline conditions i.e. no changes in irrigation strategies and cropping strategies.

- Scenario 2: Lining of canals above railway line (ARL) to prevent canal seepage, reduce groundwater recharge and increase water use efficiency; less water is required to be diverted from the Yellow River.

- Scenario 3: Pumping above railway line ( $A R L)$ and canal lining with no surface water supplies to the ARL area.

MODFLOW's ZoneBudget code calculates the groundwater budget of user-specified 10 subregions, the exchange of flows between subregions and also calculates a volumetric water budget for the entire model at the end of each time step. In the present study, whole model domain was divided into two subregions i.e. above railway line (ARL) and below railway line $(B R L)$ and a volumetric exchange of flows between subregions was calculated to analyse the impact of different land and water management scenarios.

15 In the case of Scenario 1, if no changes in irrigation strategies happen in the near future the groundwater table in the ARL area will continuously increase, and this shallow groundwater table in the ARL area causes a large amount of water losses due to fallow $E T$. Management Scenario 2 was to simulate the effect of canal lining on the water table in LIS. The scenario results showed that fallow ET will be reduced by $14.2 \%(25.51$ $\mathrm{MCM}$ ) on the whole of the model domain. Management Scenario 3 was to test out the effect of canal lining and pumping from the ARL area in LIS. The modelling results showed that fallow $E T$ will be reduced by $45.3 \%$ ( $81.36 \mathrm{MCM})$ due to a decline in water table on the whole of the model domain. The modelling result showed that reduction in non-beneficial evaporation volumes would provide two options i.e. 1) more water would be available within the LIS and more crops would be grown; and 2) water productivity would be improved. The water accounting analysis was carried out to measure water indicators which showed that $P F_{\text {depleted }}$ will be 0.55 for Scenario 2, meaning that $55 \%$

Structured hydrological analysis for targeting fallow evaporation

S. Khan et al.

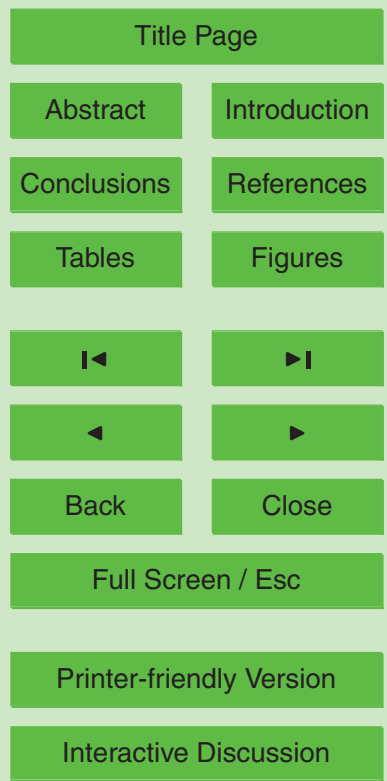

EGU 
of the depleted water is consumed by the agriculture crop and $45 \%$ is lost through nonprocess depletion. Similarly, the $P F_{\text {depleted }}$ will be 0.66 for Scenario 3, meaning that $66 \%$ of the depleted water is consumed by the agriculture crop and $34 \%$ is lost through non-process depletion. This will allow introducing more surface water supplies in the 5 groundwater-dependent areas through improved water management strategies which will ultimately lead to improve the water productivity of LIS system.

Seepage from Yellow River and channels and percolation from irrigated fields in the $A R L$ area are important sources of recharge to groundwater in the BRL area. On the other hand, too much seepage and lateral recharge increases groundwater tables, 10 which result in secondary soil salinization. Figure 8 shows a significant reduction in lateral recharge from $A R L$ to $B R L$ under different management scenarios $(1,2$ and $3)$. If there is not enough recharge to $B R L$ groundwater, the deeper groundwater table would result in increased cost of groundwater abstraction. A major policy dialogue and change is required to shift surface water supplies to $B R L$ and promote groundwater 15 pumping from ARL.

\section{Summary and conclusions}

The study examined the application of a holistic systematic approach of water accounting using remote sensing and GIS and ground water modeling to evaluate water saving options by tracking non-beneficial evaporation in Liuyuankou Irrigation System of 20 China. The lumped water balance analysis of 1988-1990 showed that the greatest unaccounted flows from the LIS are through fallow ET and can be in the range of $50 \%$. There is therefore an urgent need to improve water productivity by reducing evaporation from fallow land. However, it is only possible after the identification of fallow land through land use classification and then verification of fallow evaporation figures

advanced tools like remote sensing, which provide a more realistic estimation of $E T_{a}$ in a spatio-temporal distributed format. Therefore, it was decided to estimate seasonal actual ET by applying SEBAL for 18 NOAA AVHRR-12 images over the year
HESSD

4, 327-362, 2007

Structured

hydrological analysis

for targeting fallow

evaporation

S. Khan et al.

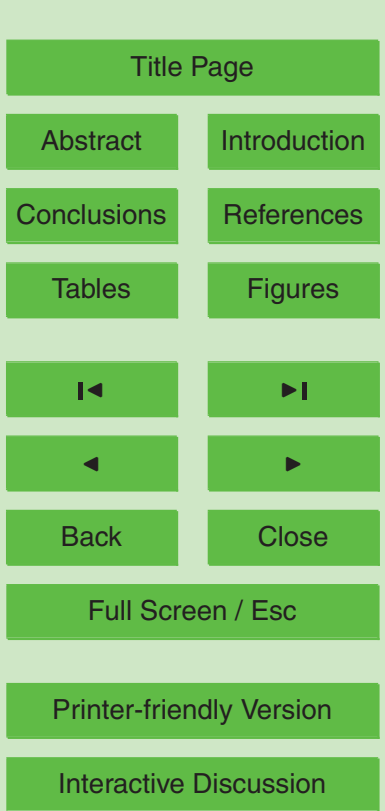

EGU 
of 1990-1991. Unsupervised classification (ISODATA clustering algorithm) was applied to two Landsat 5 TM images of the study area and the results showed that agricultural crop classification has accuracy greater than $84 \%$ and the overall accuracy and kappa coefficient associated with classification are $80 \%$ and 0.78 , respectively. SEBAL results 5 showed that a large amount of water (179.62 MCM) was lost through non-beneficial $E T$ including from fallow land, bare soil, water bodies and others during 1990-1991. Similarly, a considerable amount of water $(116.7 \mathrm{MCM})$ was lost through $E T_{s}$ from fallow land during 1990-1991, which needs to be reduced to improve water productivity of the irrigation system. The remote sensing derived $E T_{s}$ also confirms that a large amount 10 (116.7 MCM) of water can be saved by reducing $E T_{s}$ from the fallow land.

The water accounting and productivity framework was applied to measure both the water use within the system and the water productivity of LIS. The process fraction per unit of depleted water $\left(P F_{\text {depleted }}\right)$ is 0.52 for LIS, meaning that $52 \%$ of the depleted water is consumed by the agricultural crop and $48 \%$ is lost through non-process deple15 tion. The results also prove earlier findings of Khan et al. (2006b) that high amount of water is depleted through non-process depletion for LIS.

Finally, the groundwater modeling was applied to simulate three land use and water management scenarios to assess their effectiveness for water savings and impact on the groundwater levels in LIS. Considering the existing groundwater conditions as itial conditions", a number of future scenarios were evaluated by simulating the response of groundwater levels under the changed water management conditions over the next 20 years. The simulation results of Scenario 2 showed that fallow $E T$ will be reduced by $14.2 \%$ ( $25.51 \mathrm{MCM})$ by lining of canals in the ARL area, which will have an effect on water tables in the LIS. Similarly, the simulation results of Scenario 3 show that fallow $E T$ will be reduced by $45.3 \%(81.36 \mathrm{MCM})$ by canal lining, with no surface water supplies to the $A R L$ area and instead pumping from the ARL area. The reduction in non-beneficial $E T$ volumes would mean that more water would be available within LIS. This will allow introducing more surface water supplies in the groundwaterdependent areas through improved water management strategies which will ultimately
HESSD

4, 327-362, 2007

Structured

hydrological analysis

for targeting fallow

evaporation

S. Khan et al.

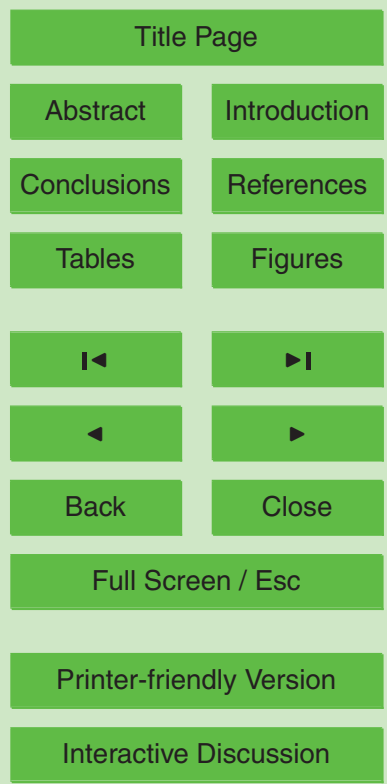


lead to improve the water productivity of LIS system.

The simulated results also showed that there is a significant reduction in lateral recharge from the $A R L$ area to the $B R L$ area under management scenario (3). In this case, there is not enough recharge to BRL groundwater, and the deepening of 5 the groundwater table increases the cost of groundwater abstraction. This will result in overdraft conditions, therefore a major policy dialogue and change is required to shift surface water supplies to the BRL area and promote groundwater pumping from the $A R L$ area. Canal lining is also believed to be an effective way to reduce losses and save water. As a result, the recharge to groundwater decreases. The cost effective10 ness of linking these economic options with a systems model of the LIS is provided by Khan et al. (2007).

Acknowledgements. The authors are grateful to Australian Centre for International Agricultural Research (ACIAR) for providing a financial support to complete the study. We are thankful to Y. Hu from IWHR, China for downloading the NOAA-AVHRR data.

\section{References}

Allen, R. G., Pereira, L. S., Raes, D., and Smith, M.: Crop evapotranspiration - Guidelines for computing crop water requirement, FAO Irrigation and Drainage Paper 56, Rome, Italy, 1998.

Bastiaanssen, W. G. M.: Regionalization of surface flux densities and moisture indicators in composite terrain, A remote sensing approach under clear skies in Mediterranean climates, Report 109, Agricultural Research Department, Wageningen, The Netherlands, 1995.

Hafeez, M. M.: Water accounting and productivity at different spatial scales in a rice irrigation system: A remote sensing approach, Doctoral Thesis, Ecology and Development Series No. 8, Center for Development Research (ZEF), University of Bonn, Cuvillier Verlag Göttingen, Germany P. 176, 2003.

Hafeez, M. M. and Khan, S.: Mapping of actual evapotranspiration over regional scale using NOAA/AVHRR satellite data, Paper presented during 13th Australasian Remote Sensing
HESSD

4, 327-362, 2007

Structured

hydrological analysis

for targeting fallow

evaporation

S. Khan et al.

\section{Title Page}

Abstract

Introduction

Conclusions

Tables

References

Figures

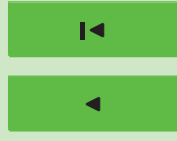

$\rightarrow$ I

Back

Close

Full Screen / Esc

Printer-friendly Version

Interactive Discussion 
and Photogrammetry Conference (ARSPC), Canberra, 20-24 November 2006, Australia, abstr. no.: 427, 2006.

Khan, S., Mushtaq, S., Luo, Y., Dawe, D., Hafeez, M. M., and Rana, T.: Economic assessment of system-level water saving through conjunctive water management options: Examples from Liuyuankou Irrigation System, China, J. Irrigation and Drainage, accepted, 2007.

Khan, S., Rana, T., Yuanlai, C., and Blackwell, J.: Can Irrigation Be Sustainable?, J. Agric. Water Manage., 80, 87-99, 2006.

Kahlown, M. A., Iqbal, M., Raoof, A., and Hanif, M.: Impact of waterlogging on major crop yields: a case study in southern Punjab, J. Drainage Water Manage., 5(2), 1-7, 2002.

10 Loeve, R., Barker, R., Dawe, D., Lin, H., and Bin, D.: Growing More Rice with Less Water: An Overview of Research in Liuyuankou Irrigation System, Henan Province, China, 2003.

Molden, D.: Accounting for water use and productivity, SWIM Paper 1, Colombo, Sri Lanka, International Water Management Institute, 1997.

Molden, D. and Sakthivadivel, R.: Water accounting to assess use and productivity of water, 15 Water Resour. Dev., 15, 55-71, 1999.

Sakthivadivel, R., Thiruvengadachari, S., Amerasinghe, U., Bastiaanssen, W. G. M., and Molden, D. J.: Performance of the Bhakra Irrigation System, India, Using remote sensing and GIS techniques, IWMI, Research Report No. 28, Colombo, Sri Lanka, 1999.

Rijsberman, F. R.: Water Scarcity: Fact or fiction?, J. Agric. Water Manage., 80, 5-22, 2006.

Tasumi, M., Bastiaanssen, W. G. M., and Allen, R. G.: Application of the SEBAL methodology for estimating consumptive use of water and stream flow depletion in the Bear River Basin of Idaho through Remote Sensing, EOSDIS Project Report, Raytheon Systems Company and the University of Idaho, USA, 2000.

Zhu, Z., Cai, X., Giordano, M., Molden, D., Hong, S., Zhang, H., Lian, Y., Zhang, X., and Xue, Y.: Yellow River Comprehensive Assessment: Basin Feature and Issues, Working Paper 57, Colombo, Sri Lanka, International Water Management Institute, 2003.

\section{Structured \\ hydrological analysis for targeting fallow \\ evaporation}

S. Khan et al.

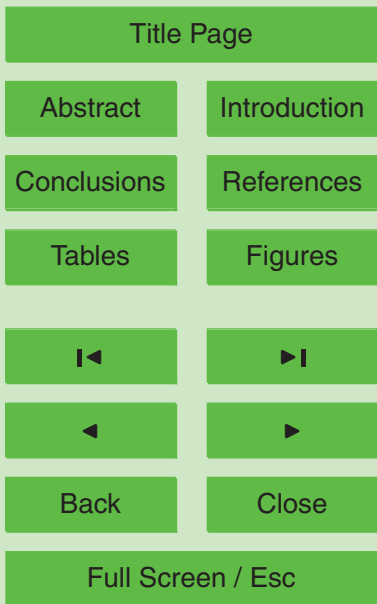

Printer-friendly Version

Interactive Discussion 


\section{HESSD}

4, 327-362, 2007

\section{Structured \\ hydrological analysis \\ for targeting fallow \\ evaporation}

Table 1. Details of NOAA AVHRR-12 Images used for the LIS area in China.

S. Khan et al.

NOAA AVHRR Images Acquisition Dates

\begin{tabular}{lll}
\hline 05 April 1990 & 21 August 1990 & 27 November 1990 \\
14 April 1990 & 02 September1990 & 25 December 1990 \\
22 April 1990 & 18 September 1990 & 12 January 1991 \\
13 May 1990 & 13 October 1990 & 31 January 1991 \\
09 June 1990 & 25 October 1990 & 25 February 1991 \\
15 July 1990 & 10 November 1990 & 16 March 1991 \\
\hline
\end{tabular}

Title Page

Abstract

Introduction

Conclusions

References

Tables

Figures

14

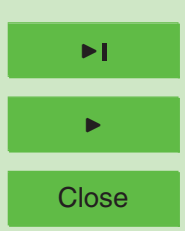

Back

Close

Full Screen / Esc

Printer-friendly Version

Interactive Discussion 


\section{HESSD}

4, 327-362, 2007

Structured

hydrological analysis

for targeting fallow

evaporation

S. Khan et al.

Table 2. Major crops, areas and yield in LIS.

\begin{tabular}{lll}
\hline CROP & YIELD $(\mathrm{kg} / \mathrm{ha})$ & AREA (ha) \\
\hline Winter wheat & $5250-6750$ & 20000 \\
Summer maize & $6750-7500$ & 6600 \\
Cotton & $750-1050$ & 6600 \\
Rice & $6000-7500$ & 4500 \\
Soybean & $85-120$ & 1300 \\
\hline
\end{tabular}

Title Page

Abstract

Introduction

Conclusions

References

Tables

Figures

14

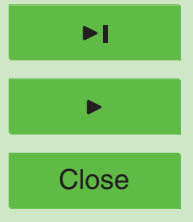

Back

Full Screen / Esc

Printer-friendly Version

Interactive Discussion 


\section{HESSD}

4, 327-362, 2007

Table 3. Yearly Water Balance of LIS from 1988-2000.

\begin{tabular}{ccccccccccc}
\hline Year & $\begin{array}{c}\text { YRWD } \\
(\mathrm{MCM})\end{array}$ & $\begin{array}{c}\mathrm{R} \\
(\mathrm{MCM})\end{array}$ & $\begin{array}{c}\text { Lateral Inflow } \\
(\mathrm{MCM})\end{array}$ & $\mathrm{IN}$ 's & $\begin{array}{c}E T_{C} \\
(\mathrm{MCM})\end{array}$ & $\begin{array}{c}E_{c} \\
(\mathrm{MCM})\end{array}$ & $\begin{array}{c}\text { Lateral Outflow } \\
(\mathrm{MCM})\end{array}$ & $d S$ & $\begin{array}{c}\text { Runoff }+E T_{f} \\
(\mathrm{MCM})\end{array}$ & OUT's \\
\hline 1988 & 162.42 & 151.08 & 94.56 & 408.06 & 309.77 & 16.24 & 4.35 & -0.34 & 82.39 & 408.06 \\
1989 & 140.26 & 255.25 & 91.43 & 486.94 & 279.40 & 14.03 & 6.81 & 55.99 & 137.52 & 486.94 \\
$\mathbf{1 9 9 0}$ & $\mathbf{1 4 8 . 8 8}$ & $\mathbf{2 9 9 . 5 6}$ & $\mathbf{8 8 . 9 2}$ & $\mathbf{5 3 7 . 3 6}$ & $\mathbf{2 8 6 . 3 3}$ & $\mathbf{1 4 . 8 9}$ & $\mathbf{3 . 2 1}$ & $\mathbf{6 9 . 7 8}$ & $\mathbf{1 6 6 . 3 6}$ & $\mathbf{5 3 7 . 3 6}$ \\
1991 & 132.37 & 203.05 & 87.44 & 422.86 & 249.56 & 13.24 & 8.24 & 13.45 & 146.61 & 422.86 \\
1992 & 101.04 & 282.25 & 85.20 & 468.49 & 274.06 & 10.10 & 9.35 & 44.22 & 140.11 & 468.49 \\
1993 & 113.50 & 234.05 & 85.98 & 433.53 & 248.35 & 11.35 & 5.95 & 10.19 & 163.64 & 433.53 \\
1994 & 76.83 & 271.15 & 86.50 & 434.48 & 294.56 & 7.68 & 5.66 & -3.74 & 135.98 & 434.48 \\
1995 & 70.94 & 207.76 & 85.40 & 364.10 & 266.19 & 7.09 & 6.16 & 4.29 & 86.35 & 364.10 \\
1996 & 105.13 & 226.47 & 83.27 & 414.87 & 211.84 & 10.51 & 3.82 & 11.13 & 181.39 & 414.87 \\
1997 & 30.80 & 140.55 & 88.12 & 259.47 & 265.41 & 3.08 & 7.85 & -104.7 & 95.73 & 259.47 \\
1998 & 7.12 & 212.19 & 90.00 & 309.31 & 250.51 & 0.71 & 6.32 & 83.71 & -25.62 & 309.31 \\
1999 & 46.14 & 212.19 & 90.00 & 348.33 & 246.89 & 4.61 & 6.00 & -9.74 & 106.57 & 348.33 \\
2000 & 52.31 & 232.88 & 90.00 & 375.19 & 274.48 & 5.23 & 6.00 & -26.10 & 121.58 & 375.19 \\
\hline
\end{tabular}

YRWD=Yellow River Water Diversions; R=Rainfall; Lateral Inflow=Seepage from Yellow River; $E T_{c}=$ Crop Water Use; $E_{c}=$ Evaporation from Canal surface; $d s=$ Groundwater storage change; and $E T_{f}=$ Fallow $E T$

\section{Structured}

hydrological analysis for targeting fallow evaporation

S. Khan et al.

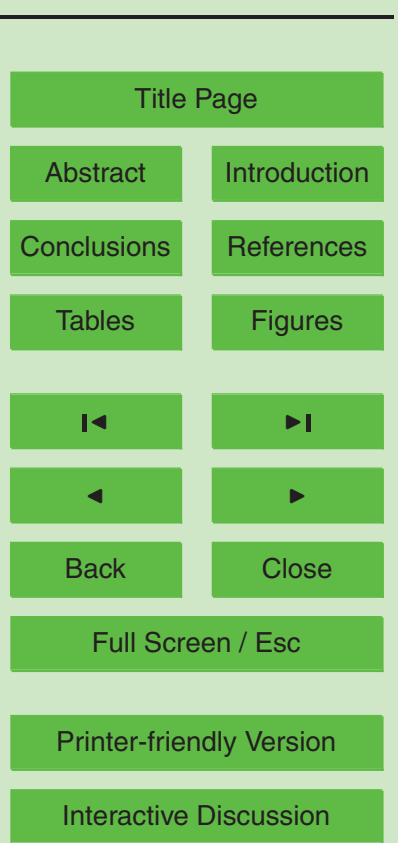


Table 4. Water accounting and its indicators of LIS for 1990-1991.

\section{HESSD}

\begin{tabular}{lc}
\hline Description & $1990-1991$ \\
\hline Total area (Ha) & 54400 \\
Agriculture area (Ha) & 26300 \\
Gross Inflow (MCM) & 605.85 \\
Irrigation & 154.87 \\
Rainfall & 373.47 \\
Pumping from Ground water & 77.51 \\
Storage Change (MCM) & -48.84 \\
Net Inflow (MCM) & 557.01 \\
Total Outflow (MCM) & 23.85 \\
Lateral Outflow & 23.85 \\
Total Depletion (MCM) & 371.68 \\
Process $E T_{\text {agriculture }}$ & 192.06 \\
Non Process $E T_{\text {non-agriculture }}$ & 179.62 \\
Available Water (MCM) & 533.16 \\
Agriculture Crop Yield (kg/Ha) & 4157 \\
Agriculture Crop Production $(\mathrm{kg})$ & $2.4 \mathrm{E}+08$ \\
Water Productivity (kg/m $\left.{ }^{3}\right)$ & \\
of Gross Inflow & 0.39 \\
of Net Inflow & 0.42 \\
of Irrigation & 1.52 \\
of $E T_{\text {crop }}$ & 1.23 \\
Depleted Fraction (-) & \\
of gross inflow & \\
of available water & 0.61 \\
Process Fraction (-) & 0.70 \\
of gross inflow & \\
of available water & 0.32 \\
of depleted water & 0.36 \\
\hline
\end{tabular}

4, 327-362, 2007

Structured

hydrological analysis for targeting fallow

evaporation

S. Khan et al.

Title Page

Abstract

Conclusions

Tables

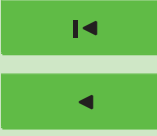

Back
Introduction

References

Figures

$>$ I

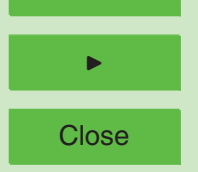

Full Screen / Esc

Printer-friendly Version 


\section{HESSD}

4, 327-362, 2007

\section{Structured \\ hydrological analysis \\ for targeting fallow \\ evaporation}

S. Khan et al.

Table 5. Average annual ground water recharge in LIS (MCM) from 1988-2000.

\begin{tabular}{lcc}
\hline Source & Average recharge (MCM) & Percent of total (\%) \\
\hline Precipitation & 148 & 55 \\
Channels Seepage & 19 & 7 \\
Yellow River Seepage & 89 & 33 \\
Field Losses from Surface Irrigation & 11 & 4 \\
Total & 267 & 100 \\
\hline
\end{tabular}

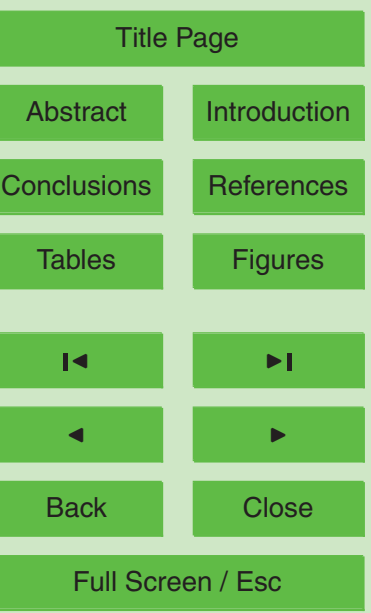

Printer-friendly Version

Interactive Discussion 


\section{HESSD}

4, 327-362, 2007
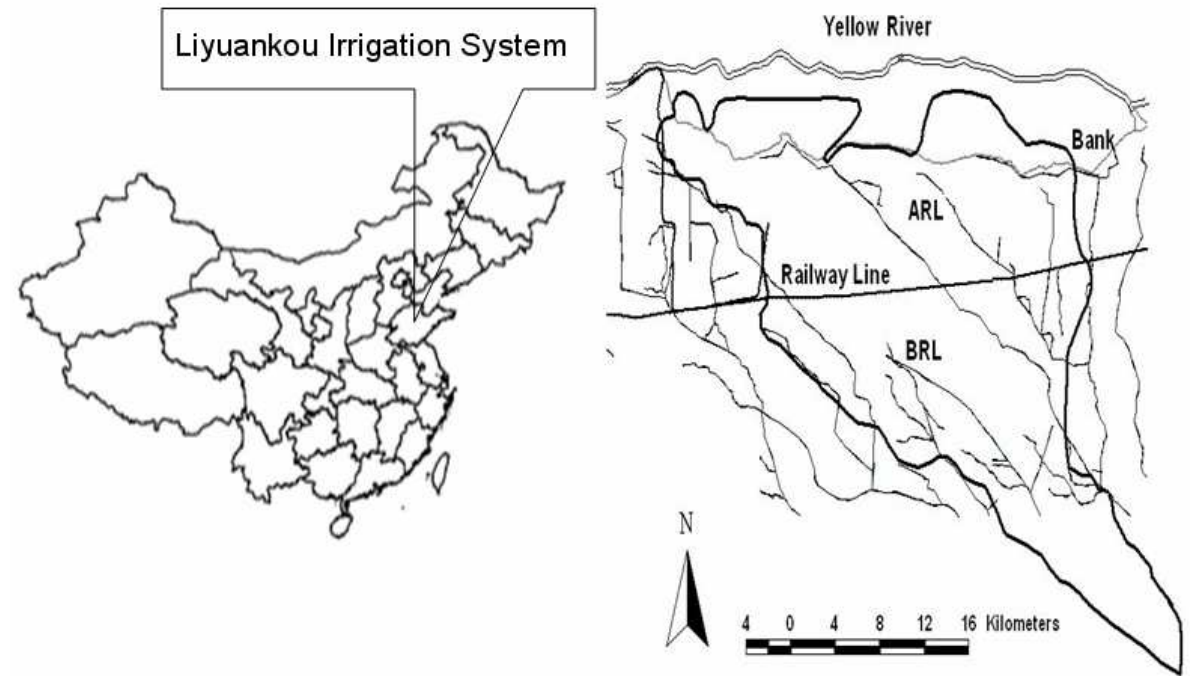

Structured

hydrological analysis for targeting fallow evaporation

S. Khan et al.

Title Page

Abstract

Introduction

Conclusions

References

Tables

Figures

14

$\rightarrow 1$

4

Back

Close

Full Screen / Esc

Printer-friendly Version

Interactive Discussion 


\section{HESSD}

4, 327-362, 2007

\begin{tabular}{|l|}
\hline Lumped Closed \\
Water Balance \\
Unknowns \\
-Fallow ET + \\
Runoff \\
\hline
\end{tabular}

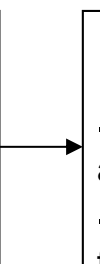

\begin{tabular}{|l|}
\hline Remote Sensing- \\
SEBAL application \\
-Beneficial ET of \\
agriculture crops \\
- Non-Beneficial ET \\
from Fallow Land
\end{tabular}
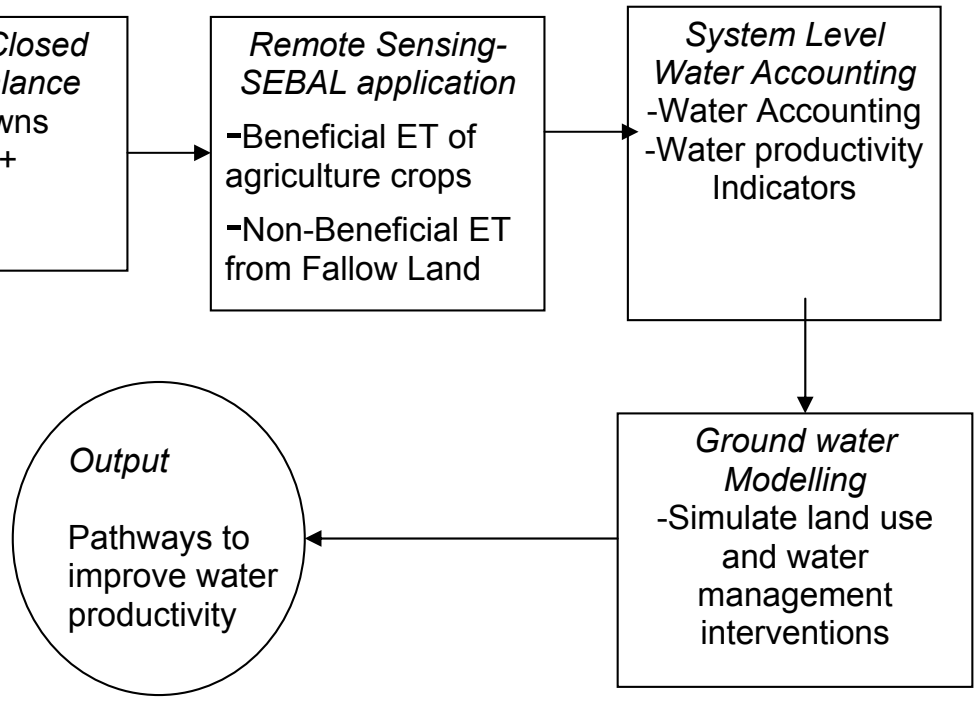

Fig. 2. Conceptual diagram for structured hydrological analysis.

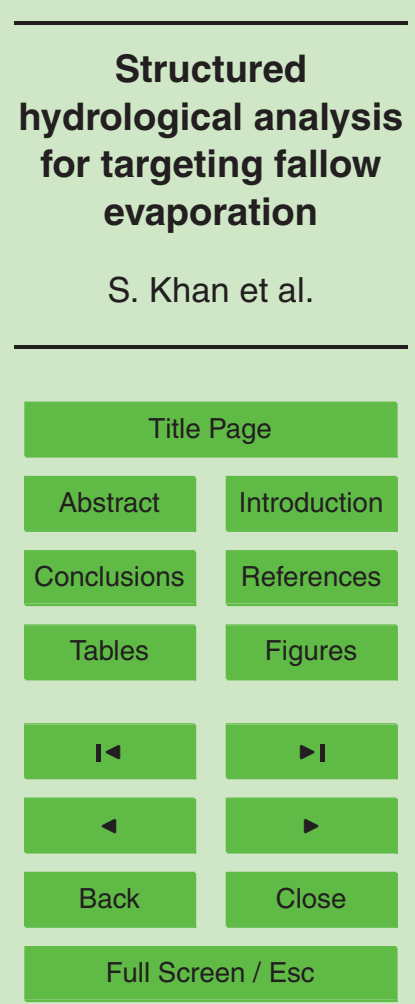

Printer-friendly Version 


\section{HESSD}

4, 327-362, 2007

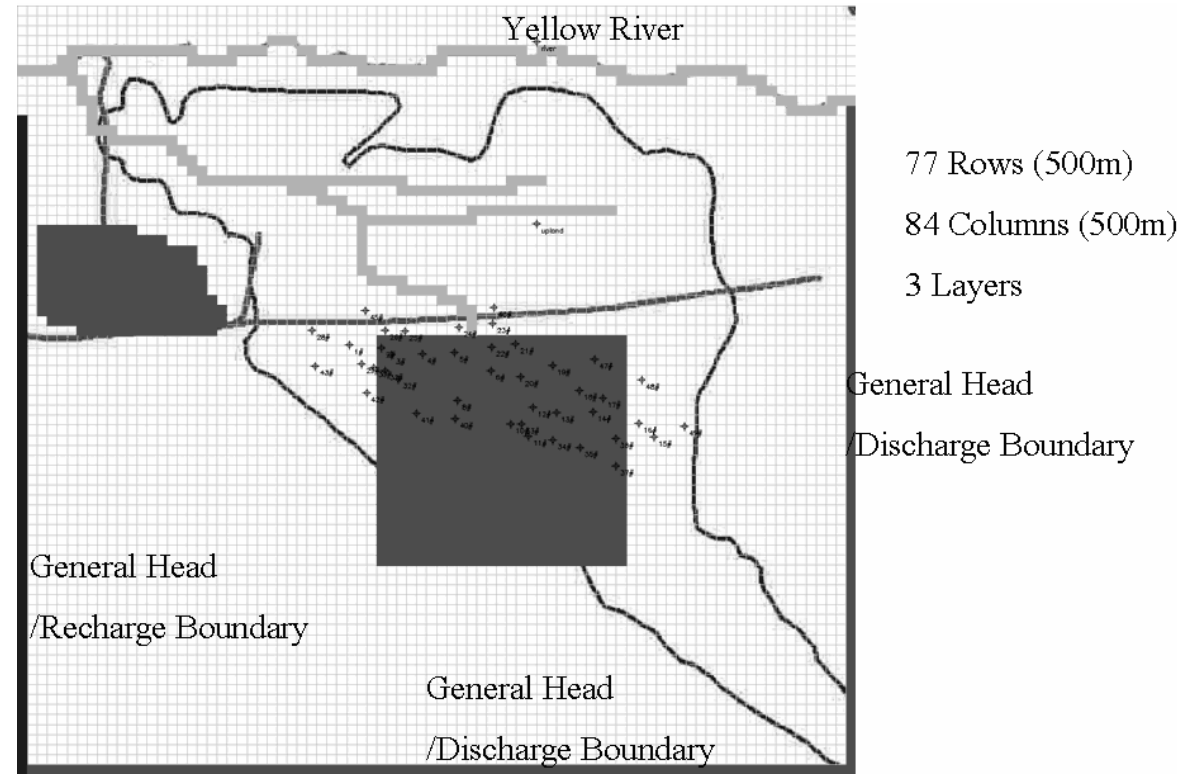

Structured hydrological analysis for targeting fallow evaporation

S. Khan et al.

Title Page

Abstract

Conclusions

Tables

14

4

Back

Full Screen / Esc

Printer-friendly Version 


\section{HESSD}

4, 327-362, 2007

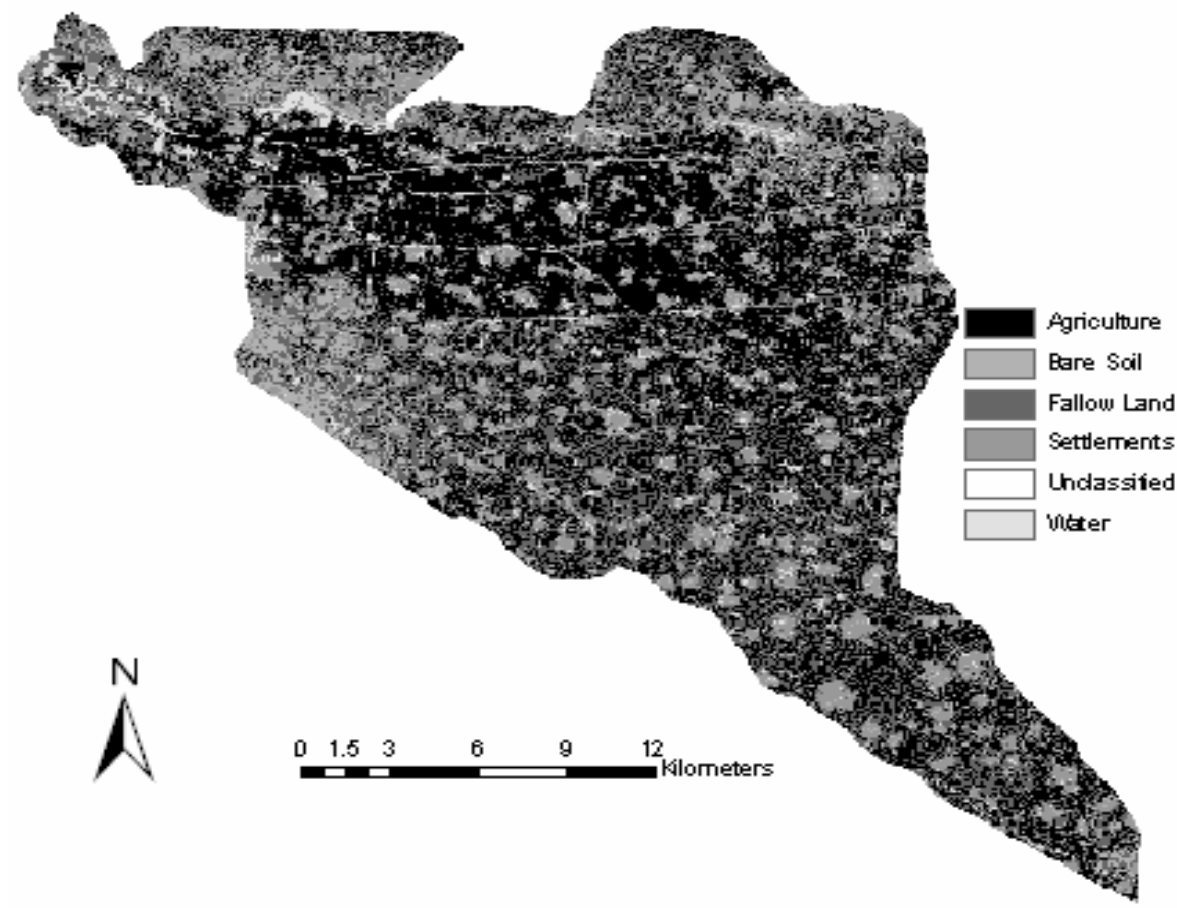

Structured

hydrological analysis for targeting fallow evaporation

S. Khan et al.

Title Page

Abstract

Conclusions

\section{Tables}

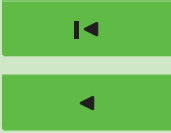

Back
Introduction

References

Figures

$\rightarrow 1$

$>$

Close

Full Screen / Esc

Fig. 4. Land use classification map of LIS area for 1990-1991.

Printer-friendly Version

Interactive Discussion 


\section{HESSD}

4, 327-362, 2007

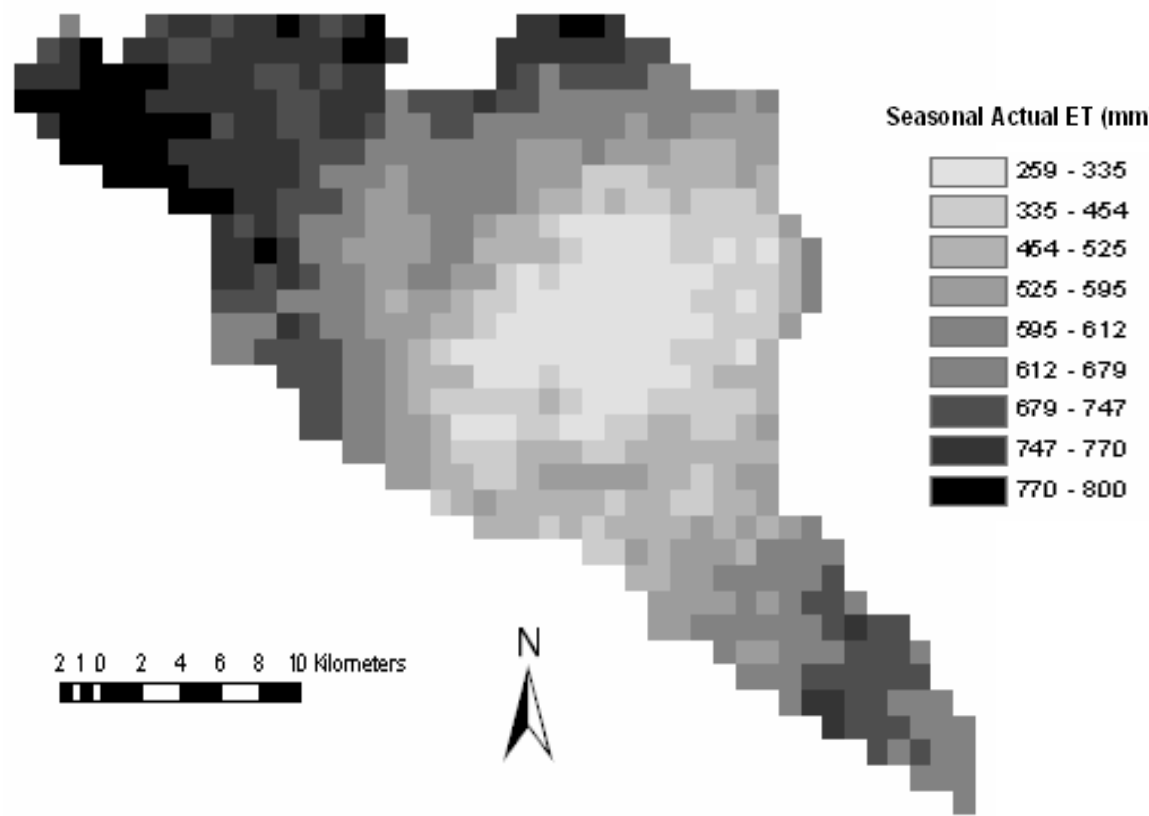

Structured hydrological analysis for targeting fallow evaporation

S. Khan et al.

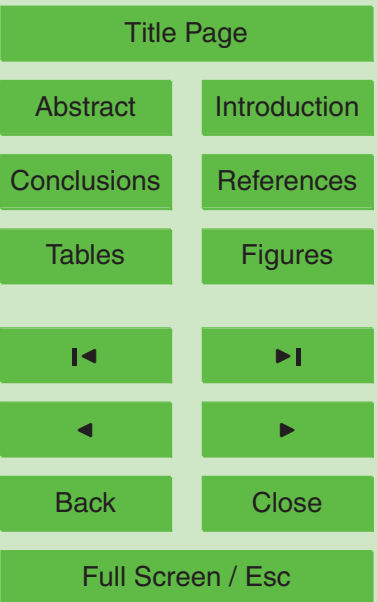
1990 to March 1991 over LIS area.

Printer-friendly Version

Interactive Discussion 


\section{HESSD}

4, 327-362, 2007

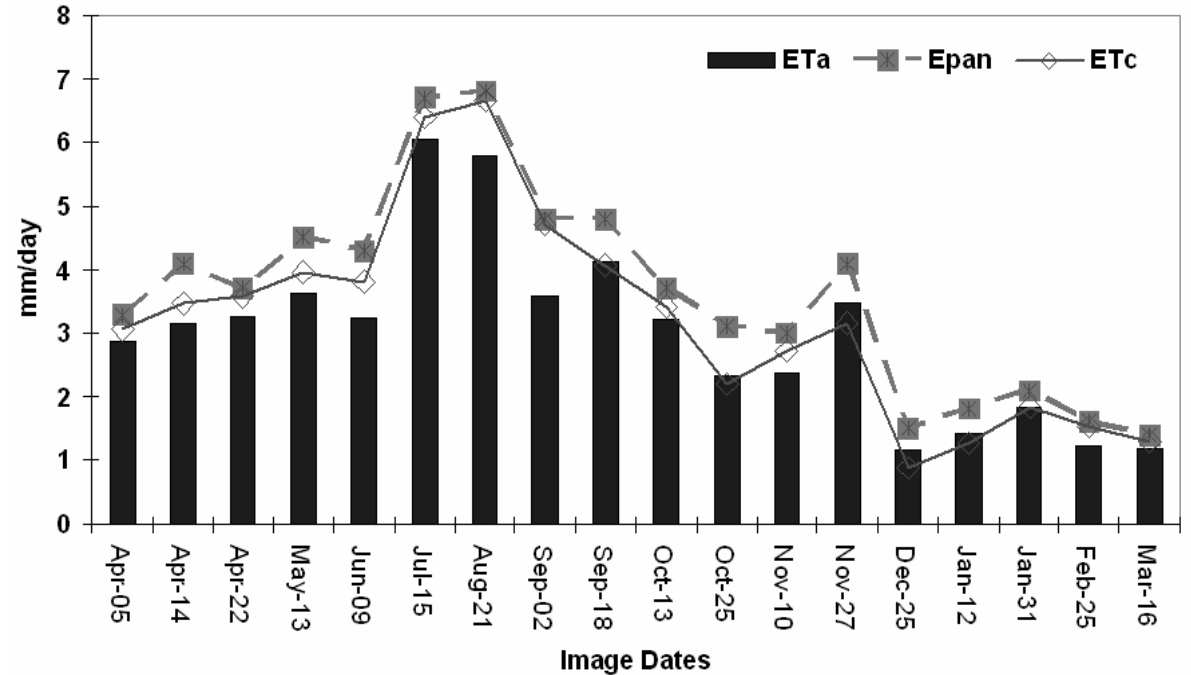

Fig. 6. Comparison of $E T_{a}$ with $E_{\mathrm{pan}}$, and $E T_{c}$, at Hubei weather station for 1990-1991.
Structured hydrological analysis for targeting fallow evaporation

S. Khan et al.

Title Page

\section{Abstract}

Conclusions

Tables

14

Back
Introduction

References

Figures

$\rightarrow$

\section{Full Screen / Esc}

Printer-friendly Version 


\section{HESSD}

4, 327-362, 2007

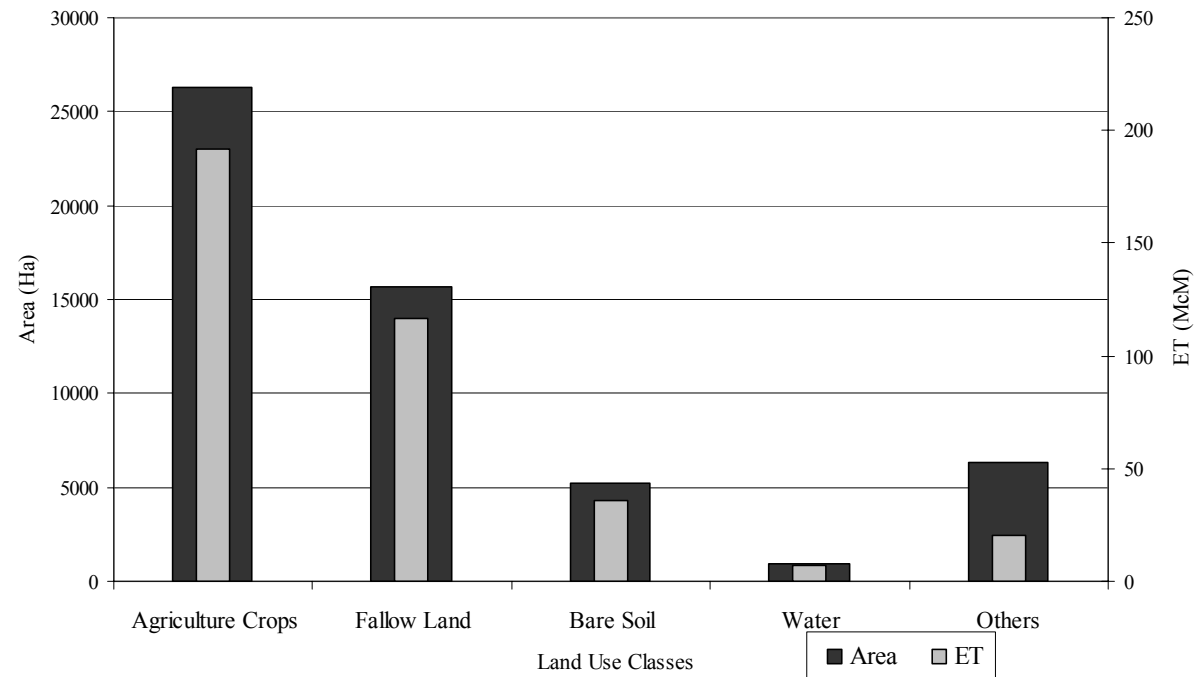

Structured

hydrological analysis

for targeting fallow

evaporation

S. Khan et al.

Title Page

Abstract

Introduction

Conclusions

References

Tables

Figures

14

$>$ I

4

Back

Close

Full Screen / Esc

Printer-friendly Version

Interactive Discussion 


\section{HESSD}

4, 327-362, 2007
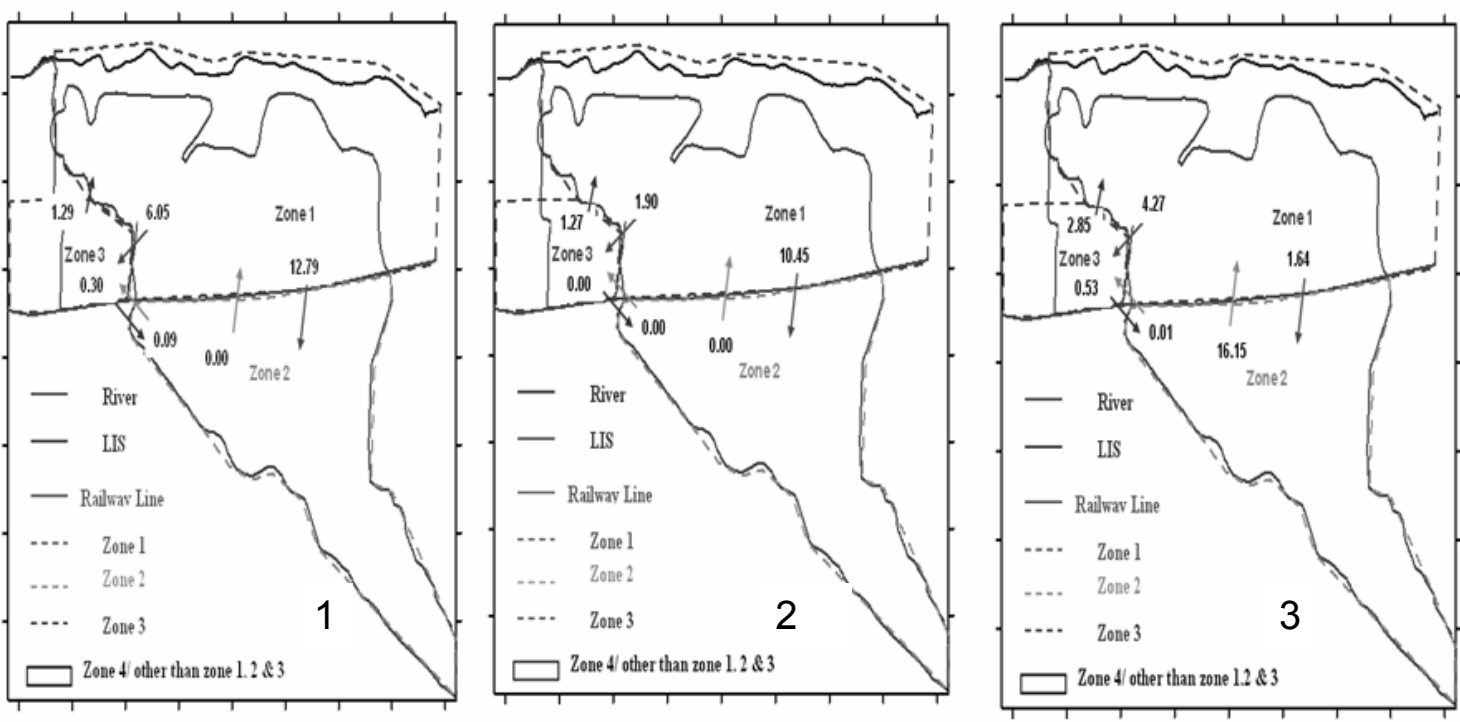

Structured hydrological analysis for targeting fallow evaporation

S. Khan et al.

Fig. 8. Exchange of flows between the zones (MCM/Year) using the scenarios; 1) start of simulation; 2) canal lining scenario; and 3) canal lining and upstream pumping scenario.

Title Page

\section{Abstract}

Conclusions

Tables

14

4

Full Screen / Esc

Printer-friendly Version 